\title{
APLIKASI EKSTRAK UMBI BAWANG TIWAI \\ ( Eleutherine americana L.Merr) \\ TERHADAP WAKTU SIMPAN ROTI BASAH
}

\author{
Suroto Hadi Saputra *)
}

\begin{abstract}
Wet bread is one of the most popular foods in Indonesia it has limitation storage time that is about 2 and 3 days in a room temperature. The usage of preservative substance to make the food durable without complay food grade standar will be dangerous for human health. Sintetics preservative made of chemical material has negative effect for health. So, another alternative must be found. Bawang tiwai tuber extract is one of the best alternatives to substitute potassium/sodium propionate, because it contains antimicroba. The purpose of this research is to get the best extraxt dosage of bawang tiwai tuber toward the duration of wet bread storage. There are two ways in researching bawang tiwai tuber extract, they are using etanol sovent and water $100^{\circ} \mathrm{C}$ were used in dosage 0,25 gram, 0,5 gram, $1 \mathrm{gram}, 1,5 \mathrm{gram}, 2 \mathrm{gram}$. Hey were compared with sintetics preservative potassium/sodium propionate with dosage 2 $\mathrm{gram} / \mathrm{kg}$ batter of wet bread. The result of the research shows that the best dosage is bawang tiwai tuber extract in $2 \mathrm{gram} / \mathrm{kg}$ wet bread batter, because it can hold out about 14 days in a room temperature.
\end{abstract}

Keywords: bawang tiwai tuber, extract, times, wet bread

\section{PENDAHULUAN}

awang tiwai (Eleutherine americana L. Merr) merupakan jenis tumbuhan yang sering digunakan sebagai obat dan rempah-rempah bagi sebagian suku yang ada di Kalimantan Timur khususnya suku Dayak. Tumbuhan ini sering terdapat di daerah dengan ketinggian $600-2000 \mathrm{~m}$ di atas permukaan laut (dpl) dan tumbuh secara alami, namun ada sebagian petani menanam bawang tiwai sebagai tanaman sela pada ladang pertanamannya.

Peneltian antimikroba telah banyak dilakukan terutama terhadap berbagai jenis tanaman rempah-rempah yang semula berkhasiat obat, Tanaman rempah-rempah dan beberapa jenis tanaman secara empiris mempunyai aktivitas antimikroba dan secara tradisional banyak digunakan sebagai pengobatan. Bawang tiwai secara tradisional sebagian suku yang ada di Kalimantan Timur digunakan sebagai obat kista, menghambat menstruasi, dan kanker.

Beberapa tanaman rempah-rempah sebagai antimikroba diantaranya adalah ekstrak daun Sereh (Cepeda, 2005), ekstrak biji Atung (Moniharopan, 1998; Syamsir, 2001), dan ekstrak daun Beluntas (Ardiansyah, 2003), ekstrak daun Annato (Cuspinera et al, 2003), ekstrak daun Andaliman (Ardiansyah, 2001), ekstrak daun Kemangi (Wan, dkk, 1998), ekstrak daun Sirih (Sukaminah, 1997), ekstrak daun Beluntas (Ardiansyah, Nuraida, L dan Andarwulan, N, 2003), ekstrak daun Salam dan daun Pandan (Murhadi, dkk, 2007) dan daun Sirih Hijau (Suliantari, dkk,
2008).

Hasil penelitian Saputra, H.S., dan Sampepana, E (2007) bahwa ekstrak Bawang Tiwai memiliki kandungan senyawa kimia antara lain protein, karbohidrat, asam karboksilat, aldehid keton, glikosida, tanin, flavonoid, dan fenol,

Pengawet pangan untuk makanan dan minuman hingga saat ini masih banyak yang menggunakan pengawet sintetis, misalnya potassium propionat merupakan pengawet sintetis yang digunakan untuk mengawetkan rotibasah. 


\section{BAHAN DAN METODE}

\section{Bahan dan Alat}

Bahan yang digunakan meliputi umbi bawang tiwai diperoleh dari pedagang rempah-rempah. Umbi bawang tiwai diiris tipis, dikeringudarakan dan dihaluskan dengan blender diperoleh sampel serbuk untuk proses ekstraksi, etanol, nyiru, toples, tatalan, gula, garam, tepung terigu, bater, mentega, ragi, pelembut, potassium propionat, ekstrak bawang tiwai, selai nenas, selai stroberi, bubuk coklat, kemasan plastik, telur, whatman paper 41, dan spidol.

Alat yang digunakan antara lain tabung reaksi, blender, alat ekstraksi (soxlet), cawan penguat, rotary vacum evaporator, gelas piala, pipet volumetrik, oven, desikator, neraca analitik, erlenmeyer, pipet tetes, corong pemisah, shaker, pisau, hot plate, reflux, spektrofotometer, botol ekstraksi, digester, lemari pendingin, buchner, rolly, dan petridish.

\section{Metode}

1. Ekstraksi

a. Etanol

Sampel $(2 \times 100 \mathrm{~g})$ direndam dengan etanol (masing-masing $3 \times 500 \mathrm{ml})$ selama 24 jam dengan dibantu pengocokan (shaking). Selanjutnya larutan ekstrak disaring dengan menggunakan kertas saring untuk kemudian dipekatkan dengan rotary evaporator. Pengeringan ekstrak selanjutnya dilakukan dengan pengeringan vakum untuk memperoleh padatan ekstrak etanol. Kuantifikasi ekstrak dihitung berdasarkan berat sampel kering udara.

b. Air

Sampel $(2 \times 100 \mathrm{~g})$ direndam dengan air $100^{\circ} \mathrm{C}$ (masing-masing $3 \times 500 \mathrm{ml}$ ) selama 24 jam dengan dibantu pengocokan (shaking). Selanjutnya larutan ekstrak disaring dengan menggunakan kertas saring untuk kemudian dipekatkan dengan rotary evaporator. Pengeringan ekstrak selanjutnya dilakukan dengan pengeringan vakum untuk memperoleh padatan ekstrak air. Kuantifikasi ekstrak dihitung berdasarkan berat sampel kering udara.

2. Aplikasi Pengawet Ekstrak Bawang Tiwai ke Produk Roti

2.1. Timbang ekstrak etanol umbi bawang tiwai 2 gram, 1 gram, 0,5 gram dan $0,25 \mathrm{gram}$; dan ekstrak air 2 gram, 1 gram, 0,5 gram, 0,25 gram; serta pengawet potasium propionat 2 gram sebagai pembanding.

2.2. Timbang tepung terigu 1300 gram, gula $3 \mathrm{~kg}, 10$ gram, beter 60 gram, mentega 60 gram, ragi 20 gram, pelembut 2 gram.

2.3. Bahan-bahan tersebut dicampurkan menjadi satu di dalam ember kemudian tambahkan air secukupnya, selanjutnya diaduk dengan menggunakan mixer, hasil adonan agak akas, waktu pengadukan \pm 15 menit, akan dihasilkan adonan roti.

2.4. Adonan dibuat lembaran dengan menggunakan mesin roli dengan waktu \pm 15 menit akan dihasilkan lembaran roti.

2.5. Buat lembaran menjadi bulatan telur, masukkan selai masing-masing ke bulatan roti tersebut kemudian bentuk bulatan memanjang, akan dihasilkan bentuk roti bulat memanjang.

2.6. Dilakukan pengkondisian agar roti mengembang dengan waktu $\pm 3,5$ jam diruang tertutup (ruang pengkondisian).

2.7. Lakukan pengovenan dengan suhu $50^{\circ} \mathrm{C}$ selama \pm 15 menit.

2.8. Lakukan pengkondisian agar suhu roti normal \pm 15 menit.

2.9. Lakukan pengemasan dengan menggunakan plastik dan direkatkan dengan siler.

3. Parameter yang diamati

1. Organoleptik yang dimati adalah bentuk, warna dan bau, berdasarkan SNI 01-38401995.

2. Cemaran mikrobiologi yang diamati adalah angka lempeng total, angka kapang, bakteri Bacillus cereus, Salmonella, kadar air berdasarkan SNI 01-3840-1995 sedangkan pengamatan cemaran jamur secara makroskopis (kaca pembesar) dan mikroskopis (mikroskop) berdasarkan Hadioetomo, S.R. (1985). 
Hasil analisa organoleptik perlakuan pengawet ekstrak umbi bawang tiwai pada Tabel 1 dan 2 .

Tabel 1. Hasil analisa organoleptik perlakuan ekstrak umbi bawang tiwai dan pengawet kalium propianat parameter organoleptik hari ke 6.

\begin{tabular}{|c|c|c|}
\hline Perlakuan (gram) & Parameter & Hasil \\
\hline Control & \multirow{10}{*}{$\begin{array}{c}\text { Organoleptik (bentuk, } \\
\text { warna,bau) }\end{array}$} & Batang, coklat kekuningan, bau normal \\
\hline $\mathrm{EOH} 2$ & & Batang, coklat kekuningan, bau normal \\
\hline $\mathrm{EOH} 1$ & & Batang, coklat kekuningan, bau normal \\
\hline $\mathrm{EOH} 0,5$ & & Batang, coklat kekuningan, bau normal \\
\hline $\mathrm{EOH} 0,25$ & & Batang, coklat kekuningan, bau nermal \\
\hline EA2 & & Batang, coklat kekuningan, bau normal \\
\hline EA1 & & Batang, coklat kekuningan, bau normal \\
\hline $\mathrm{EOH} 0,5$ & & Batang, coklat kekuningan, bau normal \\
\hline $\mathrm{EOH} 0,25$ & & Batang, coklat kekuningan, bau nermal \\
\hline PKP & & Batang, coklat kekuningan, bau normal \\
\hline
\end{tabular}

Tabel 2. Hasil analisa organoleptik perlakuan ekstrak umbi bawang tiwai dan pengawet kalium propianat parameter organoleptik hari ke 11.

\begin{tabular}{|c|c|c|}
\hline Perlakuan (gram) & Parameter & Hasil \\
\hline Control & \multirow{10}{*}{$\begin{array}{c}\text { Organoleptik (bentuk, } \\
\text { warna,bau) }\end{array}$} & Batang, coklat kekuningan, bau normal \\
\hline $\mathrm{EOH} 2$ & & Batang, coklat kekuningan, bau normal \\
\hline $\mathrm{EOH} 1$ & & Batang, coklat kekuningan, bau normal \\
\hline $\mathrm{EOH} 0,5$ & & Batang, coklat kekuningan, bau normal \\
\hline $\mathrm{EOH} \mathrm{0,25}$ & & Batang, coklat kekuningan, bau normal \\
\hline EA2 & & Batang, coklat kekuningan, bau normal \\
\hline EA1 & & Batang, coklat kekuningan, bau normal \\
\hline $\mathrm{EOH} \mathrm{0,5}$ & & Batang, coklat kekuningan, bau normal \\
\hline $\mathrm{EOH} 0,25$ & & Batang, coklat kekuningan, bau normal \\
\hline PKP & & Batang, coklat kekuningan, bau normal \\
\hline
\end{tabular}

Keterangan: $\quad \mathrm{EOH}=$ Ekstrak dengan etanol.

EA = Ekstrak dengan air.

PKP = Pengawet potassium propionat.

Kontrol= Tanpa bahan pengawet.

Berdasarkan data hasil analisa organoleptik pada tabel 1 dan 2, pemberian/perlakuan dengan dosis rendah 0,25 gram hingga 2 gram ekstrak etanol dan air $100^{\circ} \mathrm{C}$ umbi bawang tiwai tidak memberikan pengaruh terhadap perubahan bau, warna dan bentuk bila dibandingkan dengan perlakuan pengawet sintetis potassium propionat dan tanpa pemberian pengawet (control). Hal ini menunjukkan bahwa ekstrak etanol dan air $100^{\circ} \mathrm{C}$ umbi bawang tiwai tidak merubah sifat organoleptik antara lain bau, dan warna roti. Kebusukan dan kerusakan berbagai bahan pangan merupakan akibat dari reaksi kimia yang rumit sehingga aroma dan cita rasa yang sedap, zat warna dan pigmen yang elok dapat menjadi tidak sedap atau kurang elok akibat suatu reaksi kimia dalam bahan (Anonim ${ }^{\circ}$, 2002). Hal ini diperjelas Pelezer, M.J., dan Chan, E.C.S (1988) kebayakan bahan makanan merupakan media yang baik bagi pertumbuhan banyak macam mikroorganisme. Pada keadaan fisik yang menguntungkan, terutama pada kisaran suhu $7^{\circ}$ sampai $600 \mathrm{C}$, organisme akan tumbuh dan menyebabkan terjadinya perubahan dalam hal penampilan, rasa, bau serta sifat-sifat lain pada bahan makanan. Berdasarkan hasil analisa organoleptik 
sampel roti pada tabel 1 dan 2 maka hal ini memenuhi syarat mutu roti SNI 01-3840-1995.

\section{Cemaran mikrobiologi dan kadar air.}

Hasil analisa cemaran mikroba dan kadar air tersaji pada Tabel 3, dan 4.

Tabel 3. Hasil analisa cemaran mikroba perlakuan ekstrak umbi bawang tiwai dan pengawet potassium propionat parameter mikrobiologi pada hari ke 6 .

\begin{tabular}{|c|c|c|c|c|c|}
\hline \multirow{4}{*}{$\begin{array}{l}\text { Perlakuan } \\
\text { (gram) }\end{array}$} & \multicolumn{5}{|c|}{ Parameter } \\
\hline & \multicolumn{5}{|c|}{ SNI 01-3840-1995 } \\
\hline & \multirow{2}{*}{$\begin{array}{c}106 \\
\text { Angka Lempeng } \\
\text { Total (kol/g) }\end{array}$} & \multirow{2}{*}{$\begin{array}{c}104 \\
\begin{array}{c}\text { Angka Kapang } \\
\text { (kol/g) }\end{array}\end{array}$} & \multirow{2}{*}{$\begin{array}{l}\text { Bacillius } \\
\text { cereus }\end{array}$} & \multirow[b]{2}{*}{ Salmonella } & $<40 \%$ \\
\hline & & & & & Kadar air \\
\hline Control & $<1 \times 1 . E+01$ & $46 \times 1 . E+01$ & Negatif & Negatif & $24,00 \%$ \\
\hline $\mathrm{EOH} 2$ & $<1 \times 1 . E+01$ & $<1 \times 1 . E+01$ & Negatif & Negatif & $25,32 \%$ \\
\hline $\mathrm{EOH} 1$ & $<1 \times 1 . E+01$ & $<1 \times 1 . E+01$ & Negatif & Negatif & $25,17 \%$ \\
\hline $\mathrm{EOH} 0,5$ & $11 \times 1 . E+01$ & $<1 \times 1 . E+01$ & Negatif & Negatif & $22,35 \%$ \\
\hline $\mathrm{EOH} 0,25$ & $57 \times 1, E+01$ & $<1 \times 1 . E+01$ & Negatif & Negatif & $20,89 \%$ \\
\hline EA2 & $<1 \times 1 . E+01$ & $<1 \times 1 . E+01$ & Negatif & Negatif & $22,33 \%$ \\
\hline EA1 & $<1 \times 1 . E+01$ & $<1 \times 1 . E+01$ & Negatif & Negatif & $21,98 \%$ \\
\hline $\mathrm{EOH} 0,5$ & $2 \times 1 . E+01$ & $<1 \times 1 . E+01$ & Negatif & Negatif & $22,56 \%$ \\
\hline $\mathrm{EOH} \mathrm{0,25}$ & $64 \times 1 . E+01$ & $<1 \times 1 . E+01$ & Negatif & Negatif & $22,82 \%$ \\
\hline PKP & $2 \times 1 . E+01$ & $<1 \times 1 . E+01$ & Negatif & Negatif & $20,56 \%$ \\
\hline
\end{tabular}

Tabel 4. Hasil Analisa cemaran mikroba perlakuan ekstrak umbi bawang tiwai dan pengawet kalium propionat parameter mikrobiologi pada hari ke 11.

\begin{tabular}{|c|c|c|c|c|c|}
\hline \multirow{4}{*}{$\begin{array}{l}\text { Perlakuan } \\
\text { (gram) }\end{array}$} & \multicolumn{5}{|c|}{ Parameter } \\
\hline & \multicolumn{5}{|c|}{ SNI 01-3840-1995 } \\
\hline & 106 & 104 & \multirow[b]{2}{*}{$\begin{array}{l}\text { Bacillius } \\
\text { cereus }\end{array}$} & \multirow[b]{2}{*}{ Salmonella } & $<40 \%$ \\
\hline & $\begin{array}{c}\text { Angka Lempeng } \\
\text { Total }(\mathrm{kol} / \mathrm{g})\end{array}$ & $\begin{array}{c}\text { Angka Kapang } \\
(\mathrm{kol} / \mathrm{g})\end{array}$ & & & Kadar air \\
\hline Control & $<1 \times 1 . E+01$ & - & Negatif & Negatif & $24,00 \%$ \\
\hline $\mathrm{EOH} 2$ & $<1 \times 1 . E+01$ & $<1 \times 1 . E+01$ & Negatif & Negatif & $25,32 \%$ \\
\hline $\mathrm{EOH} 1$ & $<1 \times 1 . E+01$ & $<1 \times 1 . E+01$ & Negatif & Negatif & $23,53 \%$ \\
\hline $\mathrm{EOH} \mathrm{0,5}$ & $77 \times 1 . E+01$ & $<1 \times 1 . E+01$ & Negatif & Negatif & $23,88 \%$ \\
\hline $\mathrm{EOH} 0,25$ & $33 \times 1 . E+01$ & $<1 \times 1 . E+01$ & Negatif & Negatif & $26,88 \%$ \\
\hline EA2 & $<1 \times 1 . E+01$ & $<1 \times 1 . E+01$ & Negatif & Negatif & $22,33 \%$ \\
\hline EA1 & $<1 \times 1 . E+01$ & $<1 \times 1 . E+01$ & Negatif & Negatif & $20,29 \%$ \\
\hline $\mathrm{EOH} 0,5$ & $<1 \times 1, E+01$ & $<1 \times 1 . E+01$ & Negatif & Negatif & $20,43 \%$ \\
\hline $\mathrm{EOH} \mathrm{0,25}$ & $<1 \times 1 . E+01$ & $<1 \times 1 . E+01$ & Negatif & Negatif & $19,68 \%$ \\
\hline PKP & $1<\times 1 . E+01$ & $<1 \times 1 . E+01$ & Negatif & Negatif & $24,71 \%$ \\
\hline
\end{tabular}

Keterangan:

$\mathrm{EOH}=$ Ekstrak dengan etanol.

$\mathrm{EA}=$ Ekstrak dengan air.

PKP = Pengawet potassium propionat .

ALT =Angkalempeng total

AK = Angka kapang

Kontrol $=$ Tanpa bahan pengawet

Secara umum hasil analisa cemaran mikroba dan kadar air pada tabel 3 dan 4 hari ke 6 dan 11 perlakuan pengawet ekstrak umbi bawang tiwai mulai dari dosis rendah hingga tinggi, pengawet 
kalium propianat, dan kontrol bila dibandingkan dengan angka lempeng total dan angka kapang ada SNI 01-3840-1995 masih memenuhi syarat mutu. Kemudian hasil analisa untuk bakteri acillus cereus dan Salmonella negatif. Selain itu bila ditinjau dari kadar air yang terdapat pada sampel roti berkisar $18,62 \% \mathrm{~s} / \mathrm{d} 25,32 \%$ masih di bawah $40 \%$ dari standar mutu SNI 01-3840-1995 untuk produk roti. Sesuai pendapat Pelezer, M.J., dan Chan, E.C.S (1988) kebanyakan mikroorganisme suatu spesimen pangan dapat memberikan keterangan yang mencerminkan mutu bahan mentahnya, keadaan sanitasi pada pengolahan pangan tersebut, serta keefektifan metode pengawetannya. Untuk melihat daya awet perlakuan ekstrak umbi bawang tiwai dengan pelarut etanol dan air dari cemaran mikroba tersaji pada Tabel 5 dan 6.

Tabel 4. Hasil pengamatan mikroskopis perlakuan ekstrak umbi bawang tiwai dan potassium propionat terhadap parameter mikrobiologi.

\begin{tabular}{|c|c|c|c|c|c|c|c|c|c|c|c|c|c|c|c|}
\hline \multirow{2}{*}{$\begin{array}{c}\text { Perlakuan } \\
\text { (gram) }\end{array}$} & \multicolumn{14}{|c|}{ Waktu pengamatan (hari) } & \multirow{2}{*}{ Mikroba } \\
\hline & 1 & 2 & 3 & 4 & 5 & 67 & 7 & 8 & 91 & 011 & 12 & 13 & & 15 & \\
\hline Control & - & - & + & + & + & + & + & + & +4 & + & + & + & + & + & $\begin{array}{l}\text { Aspergillus } s p \\
\text { Talaromyces } s p\end{array}$ \\
\hline $\mathrm{EOH} 2$ & - & - & - & - & - & - & - & - & - & - & - & - & + & + & $\begin{array}{l}\text { Aspergillus sp } \\
\text { Penicilium sp }\end{array}$ \\
\hline $\mathrm{EOH} 1$ & - & - & - & - & - & - & - & - & - & - & - & + & + & + & $\begin{array}{l}\text { Aspergillus sp } \\
\text { Penicilium sp }\end{array}$ \\
\hline $\mathrm{EOH} 0,5$ & - & - & - & - & - & - & - & + & + & ++ & + & + & + & + & $\begin{array}{l}\text { Aspergillus sp } \\
\text { Penicilium sp }\end{array}$ \\
\hline $\mathrm{EOH} 0,25$ & - & - & - & - & - & + & + & + & + & ++ & + & + & + & + & $\begin{array}{l}\text { Aspergillus sp } \\
\text { Penicilium sp }\end{array}$ \\
\hline EA2 & - & - & - & - & - & - & - & - & - & - & - & - & + & + & $\begin{array}{l}\text { Aspergillus sp } \\
\text { Penicilium } \mathrm{sp}\end{array}$ \\
\hline EA1 & - & - & - & - & - & - & - & - & - & - & - & + & + & + & $\begin{array}{l}\text { Aspergillus sp } \\
\text { Penicilium sp }\end{array}$ \\
\hline $\mathrm{EOH} 0,5$ & - & - & - & - & - & - & - & + & + & ++ & + & + & + & + & $\begin{array}{l}\text { Aspergillus sp } \\
\text { Penicilium sp }\end{array}$ \\
\hline $\mathrm{EOH} 0,25$ & - & - &.- & - & - & + & + & + &.+ & ++ & + & + & + & + & $\begin{array}{l}\text { Aspergillus sp } \\
\text { Penicilium sp }\end{array}$ \\
\hline $\begin{array}{l}\text { Potassium } \\
\text { Propianat }\end{array}$ & - & - & - & - & - & - & - & - & - & - & - & - & + & + & Aspergillus $s p$ \\
\hline
\end{tabular}

Tabel 5. Hasil pengamatan makroskopis perlakuan ekstrak umbi bawang tiwai dan Potassium propionat terhadap parameter mikrobiologi.

\begin{tabular}{|c|c|c|c|c|c|c|c|c|c|c|c|c|c|c|c|c|}
\hline \multirow{2}{*}{$\begin{array}{l}\text { Perlakuan } \\
\text { (gram) }\end{array}$} & \multicolumn{15}{|c|}{ Waktu pengamatan (hari) } & \multirow{2}{*}{ Mikroba } \\
\hline & 1 & 2 & 3 & 4 & 5 & 6 & 7 & 8 & 9 & 10 & 11 & 12 & & & 15 & \\
\hline Control & - & - & - & + & + & + & + & + & + & + & + & + & + & + & + & $\begin{array}{l}\text { Aspergillus sp } \\
\text { Talaromyces sp }\end{array}$ \\
\hline $\mathrm{EOH} 2$ & - & - & - & - & - & - & - & - & - & - & - & - & - & - & + & $\begin{array}{l}\text { Aspergillus sp } \\
\text { Penicilium sp }\end{array}$ \\
\hline
\end{tabular}




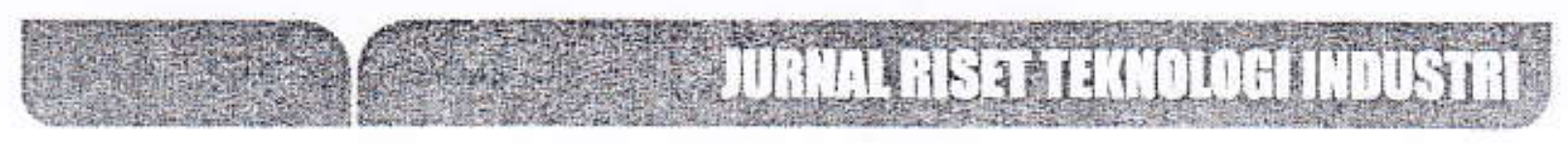

\begin{tabular}{|c|c|c|c|c|c|c|c|c|c|c|c|c|c|c|c|c|}
\hline \multirow{2}{*}{$\begin{array}{l}\text { Perlakuan } \\
\text { (gram) }\end{array}$} & \multicolumn{15}{|c|}{ Waktu pengamatan (hari) } & \multirow{2}{*}{ Mikroba } \\
\hline & 1 & 2 & 3 & 4 & 5 & 6 & 7 & 8 & 9 & 10 & 11 & & & & 15 & \\
\hline $\mathrm{EOH} 1$ & - & - & - & - & - & - & - & - & - & - & - & - & - & + & + & $\begin{array}{l}\text { Aspergillus sp } \\
\text { Penicilium sp }\end{array}$ \\
\hline $\mathrm{EOH} 0,5$ & - & - & - & - & - & - & - & - & + & + & + & + & + & + & + & $\begin{array}{l}\text { Aspergillus } s p \\
\text { Penicilium } s p\end{array}$ \\
\hline $\mathrm{EOH} \mathrm{0,25}$ & - & - & - & - & - & - & + & + & + & + & + & + & + & + & + & $\begin{array}{l}\text { Aspergillus sp } \\
\text { Penicilium sp }\end{array}$ \\
\hline EA2 & - & - & - & - & - & - & - & - & - & - & - & - & - & - & + & $\begin{array}{l}\text { Aspergillus sp } \\
\text { Penicilium sp }\end{array}$ \\
\hline EA1 & - & - & - & - & - & - & - & - & - & - & - & - & - & + & + & $\begin{array}{l}\text { Aspergillus sp } \\
\text { Penicilium sp }\end{array}$ \\
\hline $\mathrm{EOH} \mathrm{0,5}$ & - & - & - & - & - & - & - & - & + & + & + & + & + & + & + & $\begin{array}{l}\text { Aspergillus sp } \\
\text { Penicilium sp }\end{array}$ \\
\hline $\mathrm{EOH} 0,25$ & - & - & - & - & - & - & + & + & + & + & + & + & + & + & + & $\begin{array}{l}\text { Aspergillus sp } \\
\text { Penicilium sp }\end{array}$ \\
\hline $\begin{array}{l}\text { Potassium } \\
\text { Propianat }\end{array}$ & - & - & - & - & - & - & - & - & - & - & - & - & - & - & + & Aspergillus sp \\
\hline
\end{tabular}

Keterangan :

$\begin{array}{ll}\mathrm{EOH}=\text { Ekstrak dengan etanol } & \mathrm{EA}=\text { Ekstrak dengan air } \\ \mathrm{PKP}=\text { Pengawet potassium propionat } & \mathrm{AK}=\text { Angka kapang } \\ \mathrm{ALT}=\text { Angka lempeng total } & \end{array}$

Berdasarkan hasil pengamatan secara makroskopis dan mikroskopis pada tabel 5 dan 6 secara umum penggunaan ekstrak umbi bawang tiwai mulai dari dosis terendah hingga tertinggi memberikan penghambatan terhadap cemaran mikroba bila dibandingkan dengan kontrol (tanpa pengawet) ekstrak umbi bawang tiwai.

$\mathrm{Hal}$ ini diduga bahwa ekstrak umbi bawang tiwai dan potassium propianat memberikan pengaruh penghambatan terhadap mikroorganisme begitu pula untuk kontrol bahwa kondisi lingkungan pada bahan tidak baik untuk berlangsungnya mikroorganisme.

Umbi bawang tiwai mengandung fenol, menurut Robinson, T (1995) bahwa kelarutan dalam air bertambah jika gugus hidroksil makin banyak, tetapi kelarutan dalam pelarut organik yang polar umumnya tinggi. Fenol yang kelarutannya kecil, mudah larut dalam natrium hidroksida encer dalam air. Beberapa tumbuhan tampaknya menjadi tahan serangan fungus karena senyawa fenol yang dikandungnya, tetapi ketahanannya itu mungkin bersifat khas, hanya terhadap jenis fungus tertentu. Dijelaskan Riawan S (1990) bahwa fenol digunakan sebagai antiseptikum (mungkin karena mempunyai sifat mengkoagulasi protein). Selain itu koefisien fenol merupakan perbandingan konsentrasi fenol dengan konsentrasi zat untuk mematikan suatu macam bakteri dalam waktu yang sama. Saponin berfungsi sebagai sumber antibakteri dan antivirus, meningkatkan sistem kekebalan tubuh, meningkatkan vitalitas, mengurangi kadar gula dalam darah dan mengurangi penggumpalan darah (Anonim², 2002). Memperhatikan jenis-jenis bioaktivitas tersebut, mulai dari yang bersifat farmakologis, insektisida, hormon, antimikroba, toksin, dan lain-lain, mungkin tidak berlebihan apabila kita berpegang kepada suatu konsep di mana bahan-bahan kimia sumber daya alam hayati atau metabolit sekunder ini dipandang sebagai "chemical atau molecularmessenger".

Berdasarkan data pada tabel 5 dan 6 bahwa makin tinggi dosis ekstrak bawang tiwai baik menggunakan pelarut etanol dan air menunjukkan bahwa daya awet roti makin meningkat. Bila dibandingkan dengan bahan pengawet sintetis kalium propianat dengan dosis $2 \mathrm{gram} / \mathrm{kg}$ bahan dengan dosis ekstrak umbi bawang tiwai menggunakan pelarut etanol dan air dengan dosis ekstrak $2 \mathrm{gram} / \mathrm{kg}$ bahan memiliki waktu keawetan yang sama.

Adanya perbedaan keawetan pada perlakuan dosis ekstrak yang berbeda diduga bahwa bahan ekstrak umbi bawang tiwai baik dengan pelarut etanol dan air menunjukkan jumlah bahan aktif yang dikandungnya, makin tinggi dosis yang diberikan makin efektif untuk menghambat laju pertumbuhan mikroorganisme. Hal ini sesuai dengan pendapat Michael J. Pelczar, Jr dan E.C.S. Chan (1988) mengatakan bahwa salah satu faktor yang mempengaruhi antimikrobia suatu bahan 
Pengawet adalah konsentrasi atau dosis yang diberikan.

Diperjelas pendapat Robinson, T (1995) bahwa beberapa tumbuhan tampaknya menjadi tahan serangan fungus (jamur) karena senyawa fenol yang dikandungnya, tetapi ketahanannya itu mungkin bersifat khas, hanya terhadap jenis fungus (jamur) tertentu. Michael J. Pelczar, Jr dan E.C.s. Chan (1988) mengatakan bahwa fenol merupakan disinfektan terhadap mikrobial. Menurut Koes, I (2006) dan Pelezer, M.J., dan Chan, E.C.S (1988) bahwa jenis mikroorganisme yang terlibat pada roti adalah Rhizopus nigricans, Penicillium dan Aspergillus niger.

\section{KESIMPULAN DAN SARAN}

Ekstrak umbi bawang tiwai dapat dijadikan sebagai bahan pengawet roti basah, dosis terbaik untuk ekstrak umbi bawang tiwai dengan menggunakan pelarut etanol dan air sebanyak 2 gram $/ \mathrm{kg}$ bahan, waktu umur simpan roti basah selama 14 hari. Sebaiknya pelarut yang digunakan untuk mengekstrak umbi bawang tiwai adalah pelarut air dengan dosis pemakaian ke roti basah 2 gram/kg bahan.

\section{DAFTAR PUSTAKA}

Anonim ". 2002. Secang. Badan Pengkajian dan Penerapan Teknologi. Jakarta. http://www.iptek.net.id/ind/warintek/budidaya_perikanan_idx.php?doc $=3 d 7.05 / 05 / 2005$

Anonim ${ }^{\circ}$. 2002. Panduan Penerapan Bahan Tambahan Pangan. Proyek Pemberdayaan Industri Kecil Dan Menengah, Direktorat Jenderal industri Dan Dagang Kecil Menengah, Departemen Prindustrian Dan Perdagangan. Jakarta.

Badan Standardisasi Nasional, 1995. SNI 01-3840-1995. Mutu dan Cara Uji Roti. Jakarta.

Ardiansyah. 2001. Teknik Ekstraksi Komponen Antimikroba Andaliman (Zanthoxylum acanthopodium DC) dan Antarasa (Litsea cubeba). (skripsi). Bogor. FATETA Institut Pertanian Bogor.

Ardiansyah. 2003. Kajian Aktivitas Antimikroba Ekstrak Daun Beluntas (Plucea indica L.). Tesis Program Pasca Sarjana IPB. Bogor.

Ardiansyah Nuraida, L. dan Andarwulan, N. 2003. Aktivitas Antibakteri Ekstrak Daun Beluntas (Plucea indica L) Dan Stabilitas Aktivitasnya Pada Berbagai Konsentrasi Garam Dan Tingkat pH. Jurnal Teknologi dan Industri Pangan Volume XIV Nomor 2 halam 90 s.d 95. Perhimpunan Teknologi Pangan (PATPI). Bogor.

Cepeda DN. 2005. Aktivitas Ekstrak Etanol Sereh Terhadap Pertumbuhan Escherichia coli verotoksigenik. (Tesis). Bogor. Program Pascasarjana Institut Pertanian Bogor.

Cuspinera VG., Westhoff DC, Rankin SA. 2003. Antimicrobial Properties of Commercial Annatto Extracts Against Selected Pathogenic, Lactic cid, and Spoilage Microorganisms. J Food Prot 46:206-2009.

Hadioetomo, S.R., 1985. Mikrobiologi Dasar Dalam Praktek. PT. Gramedia. Jakarta.

Koes, I. 2002. Mikrobiologi Menguak Dunia Dunia Mikroorganisme Jilid 2. Yrama Widya. Bandung. Michael J. Pelczar, Jr., dan E.C.S. Chan. 1988. Dasar-Dasar Mikrobiologi 2. Universitas Indonesia Press. Jakarta.

Moniharopan T. 1998. Kajian Fraksi Bioaktif Dari Buah Atung (Parinarium glaberimum Hassk) Sebagai Bahan Pengawet Pangan. (Desertasi). Bogor. Program Pascasarjana Institut Pertanian Bogor.

Murhadi, Suharyono, AS., dan Susilawati. 2007. Aktivitas Antibakteri Ekstrak Daun Salam Dan Daun Pandan. Jurnal Teknologi Dan Industri Pangan Volume XVIII Nomor 1 halam 17 s.d 23. Perhimpunan Teknologi Pangan (PATPI). Bogor.

Pelezer, M.J., dan Chan, E.C.S 1988. Dasat-Dasar Mikrobiologi 2. Universitas Indonesia Press. Jakarta.

Riawan S. 1990. Kimia Organik. Bina Rupa Aksara. Grogol

Robinson. T. 1995. Kandungan Organik Tumbuhan Tingkat Tinggi. Penerbit ITB. Bandung Sukarminah, E. 1997. Kajian Sifat Antimikroba Ekstrak Daun Sirih (Piperbattle L.)

Terhadap Pertumbuhan Mikroba Perusak Dan Patogen Makanan (Tesis). Institut Pertanian Bogor Program Pascasarjana. Bogor. 
Suliantari, Jenie, B.S.L., Suhartono dan Apriyantono, A., 2008. Aktivitas Antimikroba Ekstrak Sirih Hijau (Piper betle L.) Terhadap Bakteri Patogen Pangan. Jurnal Teknologi Dan Industri Pangan Volume XIX Nomor 1 halam 1 s.d 6. Perhimpunan Teknologi Pangan (PATPI). Bogor

Saputra, H.S., dan Sampepana E, 2007. Analisa Kandungan Kimia dan Pemanfaatan Bawang Tiwai (Eleutherine americana L. Merr) untuk Bahan Baku Industri. Jurnal Riset Teknologi Industri Vol.1 No.1 Juni 2007. Balai Riset dan Standardisasi Industri. Samarinda.

Syamsir E. 2001. Mempelajari Stabilitas Aktivitas Antimikroba Ekstrak Biji Atung (Parinarium glaberimum Hassk) Selama Penyimpanan Terhadap Staphylococcus aureus (Tesis). Bogor. Program Pascasarjana Institut Pertanian Bogor.

Wan, J., Wilcock, A., and Coventry, M.J. 1998. The Effect of Essential Oils of Basil on the Growth of Aeromonas hydrophila and Pseudomonas fluorencens. JAppl Microbiol 84:152-158. 